\title{
Program ramowy Horyzont Europa czynnikiem wspierającym transformację energetyczną kraju
}

\section{Horizon Europe framework programme as a factor supporting the energy transformation of the country}

\author{
Maria Ciechanowska \\ Instytut Nafty i Gazu - Państwowy Instytut Badawczy
}

\begin{abstract}
STRESZCZENIE: W artykule omówiono założenia ramowego programu Horyzont Europa, ustanowionego przez Komisję Europejską na lata 2021-2027, w zakresie badań naukowych i innowacji. Konstrukcja tego programu oparta jest na trzech filarach, odpowiadających kolejno: za stworzenie odpowiednich warunków dla naukowców do zdobycia wysokiego poziomu wiedzy i umiejętności, za wykorzystanie kapitału intelektualnego Europy, za skoncentrowanie się na rozwoju kluczowych technologii i innowacyjnych rozwiązań w wybranych obszarach. Przedstawiono grupy tematyczne programu Horyzont Europa, obejmujące m.in. zdrowie, cyfryzację, klimat, energię, przemysł, biogospodarkę. Zwrócono uwagę na organizację międzynarodowej współpracy w dziedzinie badań i innowacji, w której szczególne miejsce w nadchodzącej perspektywie programowej zajmuje partnerstwo. Partnerstwo rozumiane tu jest jako współdziałanie zespołów badawczych państw członkowskich UE, sektora prywatnego, fundacji czy stowarzyszeń przy podejmowaniu i realizacji inicjatyw wspierających rozwój oraz przy wdrażaniu programu badań. Podkreślono miejsce technologii wodorowych w rozwoju różnych sektorów gospodarki, począwszy od energetyki, transportu samochodowego, kolejowego, lotniczego, żeglugi lądowej i morskiej, poprzez ogrzewnictwo i klimatyzację, po przemysł petrochemiczny, chemiczny czy stalowy. We wdrażaniu tych technologii ogromną rolę do spełnienia ma przemysł gazowniczy, dysponujący zarówno doświadczeniem, jak i infrastrukturą do transportu gazu ziemnego z dodatkiem wodoru czy gazu i wodoru, a także do magazynowania wodorowego nośnika energii. Przedstawiono korzyści wynikające z realizacji programu Horyzont Europa. Oprócz tych najważniejszych, związanych z głównym celem, jakim jest wspomożenie działań na rzecz uczynienia Europy kontynentem neutralnym dla klimatu do 2050 r., zwrócono uwagę na zapewnienie otwartego dostępu do publikacji i danych wynikowych oraz na wzmocnienie międzynarodowej współpracy zespołów badawczych. Zaprezentowano główne założenia i cele programu Cyfrowa Europa oraz obszary objęte finansowaniem (m.in. sztuczna inteligencja, zaawansowane umiejętności cyfrowe, szerokie wykorzystanie nowoczesnych technologii cyfrowych w całej gospodarce). Obydwa programy, Horyzont Europa, jak i Cyfrowa Europa, są kompatybilne ze strategią UE Europejski Zielony Ład.
\end{abstract}

Słowa kluczowe: badania naukowe i innowacje, sektor energetyki, technologie wodorowe, partnerstwo europejskie.

ABSTRACT: The article discusses the objectives of the Horizon Europe framework programme, conceived by the European Commission for 2021-2027, for the purposes of research and innovation. This programme is structured around three pillars, focusing on: creating the right conditions for researchers to acquire a high level of knowledge and skills, harnessing Europe's intellectual capital, development of key technologies and innovative solutions in selected areas. The thematic groups of Horizon Europe have been presented, including: health, digital solutions, climate, energy, industry, bioeconomy. Attention has been paid to the organisation of international cooperation in the scope of research and innovation, where partnership has a special place in the upcoming programme perspective. The partnership is understood here as cooperation between research teams from EU Member States, the private sector, foundations or associations in undertaking and carrying out initiatives to support the development and implementation of the research agenda. The place of hydrogen technology in the development of various sectors of the economy was emphasised - from energy, road, rail, air, inland and sea transport, through heating and air conditioning, to the petrochemical, chemical and steel industries. The gas industry has a great role to play in the implementation of these technologies, having both the experience and the infrastructure to transport natural gas with the addition of hydrogen or to store hydrogen as an energy carrier. The benefits of implementing Horizon Europe have been presented. In addition to the chief benefits, related to the main objective of helping to make Europe a climate-neutral continent by 2050, attention has been paid to ensuring open access to publications and raw research results as well as to reinforcing international cooperation between research teams. The main assumptions and objectives of the Digital Europe programme have been presented, as well as the areas covered by

Autor do korespondencji: M. Ciechanowska, e-mail: maria.ciechanowska@inig.pl

Artykuł nadesłano do Redakcji: 31.08.2020 r. Zatwierdzono do druku: 28.09.2020 r. 
funding (e.g. artificial intelligence, advanced digital skills, wide use of modern digital technologies in the entire economy). Both Horizon Europe and Digital Europe are compatible with the European Green Deal strategy of the EU.

Key words: research and innovation, energy sector, hydrogen technologies, European partnership.

\section{Program Horyzont Europa}

Ramowy program Horyzont Europa, ustanowiony na lata 2021-2027, jest programem inwestycyjnym w zakresie badań naukowych i innowacji, ściśle związanym z urzeczywistnieniem głównych celów strategii Unii Europejskiej o nazwie Europejski Zielony Ład (Komisja Europejska, 2019b; Regionalne Centrum Innowacji i Transferu Technologii, 2020). Konstrukcja tego programu oparta jest na trzech filarach:

\begin{tabular}{|l|l|c|}
\hline \multicolumn{1}{|c|}{ Filar I } & \multicolumn{1}{c|}{ Filar II } & Filar III \\
\hline \hline $\begin{array}{l}\text { Doskonała baza } \\
\text { naukowa }\end{array}$ & $\begin{array}{l}\text { Globalne wyzwania i eu- } \\
\text { ropejska konkurencyj- } \\
\text { ność przemysłowa }\end{array}$ & Innowacyjna Europa \\
\hline
\end{tabular}

Filar I ma za zadanie wzmocnienie pozycji UE jako lidera badań naukowych poprzez stworzenie warunków do zdobywania wysokiego poziomu wiedzy i umiejętności. Zadanie to będzie realizowane poprzez:

- działania Europejskiej Rady ds. Badań Naukowych (European Research Council, ERC) - niezależnej instytucji wspierającej pionierskie, wysokiej jakości badania naukowe poprzez promowanie najlepszych naukowców wraz z zespołami, niezależnie od dziedziny badań;

- program pn. „Maria Skłodowska-Curie” (Komisja Europejska, 2020), którego działania będą koncentrować się na rozwoju i wykorzystaniu kapitału intelektualnego Europy, m.in. poprzez:

- opracowanie nowych, innowacyjnych i kreatywnych systemów szkoleń, odpowiadających coraz bardziej interdyscyplinarnym wymogom w zakresie badań naukowych i innowacji,

- zwiększenie mobilności naukowców w dziedzinie badań, w skali europejskiej i międzynarodowej;

- działanie pn. „Infrastruktury badawcze”, mające na celu zintegrowanie i wzajemne połączenie infrastruktury badawczej światowej klasy (Komisja Europejska, 2019a).

Filar II koncentruje się na tych globalnych kierunkach, które stanowią podstawę polityki UE i jej zrównoważonego rozwoju. Chodzi tu o rozwój kluczowych technologii i innowacyjnych rozwiązań w następujących grupach tematycznych:

- Technologie cyfrowe, przemysł i przestrzeń kosmiczna;

- Bezpieczeństwo cywilne na rzecz społeczeństwa;

- Zdrowie;
- Żywność, biogospodarka, zasoby naturalne, rolnictwo i środowisko;

- Kultura, kreatywność i społeczeństwa integracyjne;

- Klimat, energetyka i mobilność.

Filar III - Innowacyjna Europa. Zadania tego filaru koncentrują się na utworzeniu całego systemu innowacyjnego, w tym na stymulowaniu nowych technologii i innowacji, kształtujących przyszłość Europy. Realizowane one będą poprzez działania:

- Europejskiej Rady ds. Innowacji, wspierającej innowacje o przełomowym znaczeniu i posiadające potencjał do tworzenia rynków;

- europejskich ekosystemów innowacji, promujących realizację wspólnych transgranicznych programów innowacyjnych;

- Europejskiego Instytutu Innowacji i Technologii (EIT), skupiającego instytucje wspierające innowacje.

Proponowany jest także filar horyzontalny, łączący poszczególne grupy tematyczne i obszary w wytypowanym istotnym dla rozwoju aspekcie, np.:

- innowacyjne małe i średnie przedsiębiorstwa;

- Europejska Chmura Naukowa;

- koordynowane przez Europejski Instytut Innowacji i Technologii (EIT) klastry dla nowych rozwiązań w zakresie m.in. energii, cyfryzacji, surowców do produkcji czy mobilności miejskiej.

W wyniku konsultacji z państwami UE Komisja Europejska zidentyfikowała 38 obszarów tematycznych, które powinny stać się wiodącymi, by zrealizować podstawowe misje UE.

\section{Obszary tematyczne związane z energetyką}

Analizując obszary tematyczne pod kątem czekającej nas transformacji krajowego przemysłu naftowego i gazowniczego, dążącej m.in. do zastąpienia docelowo paliw kopalnych nowym nośnikiem energii, jakim jest wodór, minimalizujący degradację środowiska naturalnego, można zauważyć, że większość z tych obszarów jest bezpośrednio lub pośrednio związana z energetyką.

Obszary tematyczne programu Horyzont Europa to m.in.:

- Inteligentne sieci i usługi;

- Europejska metrologia;

- Przemysł neutralny pod względem emisji $\mathrm{CO}_{2} \mathrm{i}$ o obiegu zamkniętym;

- Służba geologiczna dla Europy; 
- Czyste lotnictwo;

- Czysty wodór;

- Ekologiczne budownictwo;

- Bezemisyjny transport;

- Zrównoważone, inteligentne i sprzyjające włączeniu społecznemu miasta i społeczności;

- Przejście na czystą energię.

Do sektorów gospodarki, w których będą promowane technologie wodorowe, zalicza się także transport samochodowy (osobowy i cargo), kolejowy, morski, żeglugowy, lotniczy, ogrzewnictwo i klimatyzację, przemysł petrochemiczny i chemiczny, cementowy i hutniczy (Dorociak i Tomecki, 2019; Międzynarodowa Agencja Energii, 2019; Łoskot-Strachota, 2020).

W tym zakresie prowadzonych jest szereg prac badawczych wyprzedzających, potwierdzających możliwość wykorzystania na obecnym etapie mieszaniny gazu ziemnego i wodoru, przesyłania jej siecią gazowniczą, magazynowania tej mieszaniny, a także użytkowania poprzez zasilanie urządzeń u odbiorców końcowych (Jaworski et al., 2019).

W sektorze energetyki istotną rolę spełniają obecnie ropa naftowa i gaz ziemny. Udział węglowodorów w miksie energetycznym będzie z każdym rokiem malał na rzecz OZE i wodoru otrzymywanego przy wykorzystaniu energii z odnawialnych źródeł energii czy z paliw kopalnych.

Należy także zwrócić uwagę na biopaliwa wyprodukowane z surowców pochodzenia naturalnego (odpady rolnicze, leśne, rośliny energetyczne itp.). Biogaz/biometan są postrzegane jako paliwa bardzo perspektywiczne.

Przyszły system energetyczny, planowany i zarządzany najprawdopodobniej jako całość, łączący różne nośniki energii, różne infrastruktury i różne sektory, będzie funkcjonował w obiegu zamkniętym przy wykorzystaniu m.in. energii z bioodpadów.

Porównując stan obecny do tego, który chcemy osiągnąć, widać, że problemów do rozwiązania jest niezwykle dużo i dlatego przed jednostkami naukowymi i sektorem energetycznym stoi zarówno wyzwanie, jak i szansa, by włączyć się w nurt transformacji gospodarki i uczynić ją realną.

\section{Partnerstwo europejskie w programie Horyzont Europa (HE)}

Wyżej wymieniony ramowy program UE wprowadza ujednolicony sposób finansowania i organizacji współpracy państw członkowskich w dziedzinie badań naukowych i innowacji na lata 2021-2027. Co więcej, słowo „współpraca” zostaje zastąpione w nowej perspektywie przez ,partnerstwo”, mające zdecydowanie szersze pozytywne konotacje (bycie partnerem, równe traktowanie, zaufanie, pomoc, kooperacja, koleżeństwo...).
Powstanie nowa generacja partnerstw o prostych strukturach organizacyjnych, strategicznie ukierunkowanych na kompleksowe rozwiązanie określonych problemów (od badań i innowacji po wdrożenie), skoncentrowanych i spójnych z misjami i polityką UE.

Przewiduje się powstanie trzech rodzajów partnerstw, takich jak:

- wspólnie zaprojektowane partnerstwo w ramach programu HE - wyniki wdrażane niezależnie przez poszczególnych partnerów;

- wspólnie zaprogramowane partnerstwo, lecz przy podjęciu równocześnie przez strony zobowiązań w postaci wkładów finansowych lub udziałów niepieniężnych, współfinansowane z programu HE;

- partnerstwo zinstytucjonalizowane - w przypadku potrzeby silnej integracji w perspektywie długoterminowej.

Partnerstwo europejskie oznacza zatem inicjatywę, w ramach której UE wraz z państwami członkowskimi, sektorem prywatnym, fundacjami, stowarzyszeniami oraz innymi zainteresowanymi stronami zobowiązuje się do wspierania rozwoju i wdrażania programu badań i innowacji w danym obszarze.

\section{Korzyści wynikające z realizacji programu UE}

Program Horyzont Europa został pomyślany wieloaspektowo i wielopłaszczyznowo, na miarę XXI wieku, a jego celem jest wspomożenie działań na rzecz uczynienia Europy kontynentem neutralnym dla klimatu. Korzyści z uczestnictwa w tym programie jest wiele, zarówno wymiernych, jak i niewymiernych, o różnej skali oddziaływania. Poniżej zasygnalizowano trzy z nich:

1. Jednym z warunków koniecznych do spełnienia przez realizatorów projektów w ramach HE jest zapewnienie otwartego dostepu do publikacji, do danych wynikowych z badań, zgodnie z zasadą, że dostęp ten powinien być „otwarty w największym możliwym zakresie, zamknięty tylko w koniecznym". Otwarty dostęp do publikacji ma zapewnić platforma chmurowa (European Open Science Cloud), której zadaniem jest także zarządzanie danymi, by były one dostępne, łatwe do znalezienia i możliwe do ponownego wykorzystania. Początkowo platforma ta ma być udostępniona europejskim środowiskom naukowym, później ma być rozszerzona na sektor publiczny i prywatny. Takie podejście ma istotne znaczenie dla ogólnie pojętego procesu integracji (zespołów, badań, infrastruktury), ale przede wszystkim dla właściwie pojętego partnerstwa.

2. Bardzo ważnym elementem generującym rozwój jest wzmocnienie międzynarodowej współpracy pomiędzy europejskimi zespołami sektora badań naukowych i innowacji 
poprzez wspólne działanie w sieciach i wspólne rozwiązywanie problemów, zwiększenie mobilności naukowców czy promowanie doskonałości.

3. Podstawowym założeniem programu Horyzont Europa jest jego całkowita kompatybilność ze strategią UE pn. Europejski Zielony Ład. Planowana w efekcie transformacja przemysłowa, środowiskowa czy cyfrowa stworzy nowe specjalizacje, nowe możliwości rynkowe i nowe miejsca pracy. Będzie stanowiła kolejną rewolucję w rozwoju społeczeństw. I to już się dzieje w przestrzeni, w której żyjemy.

\section{Program Cyfrowa Europa}

Prezentując założenia i cele ramowego programu Horyzont Europa, nie można nie zwrócić uwagi na drugi program Cyfrowa Europa, który jest instrumentem kompleksowo wspierającym nowoczesny rynek cyfrowy. Bez tego rynku transformacja przemysłowa nie byłaby możliwa. Dlatego oba programy są ze sobą ściśle związane, przede wszystkim poprzez cel nadrzędny, jakim jest uczynienie europejskiego przemysłu konkurencyjnym w skali globalnej, suwerennym technologicznie i kształtującym cyfrową przyszłość Europy, z korzyścią dla obywateli, biznesu i środowiska (Balcewicz, 2020).

Program Cyfrowa Europa będzie realizowany w latach 2021-2027 i zapewni finansowanie projektów w pięciu obszarach:

- obliczenia superkomputerowe;

- sztuczna inteligencja;

- cyberbezpieczeństwo;

- zaawansowane umiejętności cyfrowe;

- szerokie wykorzystanie technologii cyfrowych w całej gospodarce i przez wszystkie grupy społeczne.

DigitalEurope, firma będąca organizacją reprezentującą europejski przemysł technologii cyfrowej, określiła wskaźniki na rok 2025 będące według tej organizacji miarą sukcesu realizacji programu Cyfrowa Europa. Wskaźniki te odzwierciedlają także niezbędne kierunki działań, by UE odnalazła swoje miejsce w globalnej erze cyfrowej. A oto niektóre z wyżej wymienionych wskaźników (DigitalEurope, 2019):

- 90\% osób, które nie mają formalnego wykształcenia, powinno być regularnymi użytkownikami internetu;

- $6 \%$ pracujących kobiet powinno być specjalistami w zakresie technologii informacyjno-komunikacyjnych (TIK);

- każde gospodarstwo domowe powinno mieć dostęp do technologii 4G (czwarta generacja telefonii komórkowej);

- $15 \%$ wszystkich materiałów stosowanych w gospodarce powinno być odzyskiwanych i ponownie wykorzystywanych;

- 10\% wydatków przeznaczonych na badania i innowacje powinno być ukierunkowanych na technologie TIK;
- $3 \%$ PKB kraje europejskie powinny przeznaczać na badania i innowacje;

- 70\% gospodarstw europejskich powinno mieć szerokopasmowy dostęp do internetu.

Wskaźniki te pozwolą m.in. określić pozycję danego europejskiego partnera na cyfrowej liście rankingowej.

\section{Podsumowanie}

Całe środowisko naukowe, ale także stowarzyszenia i organizacje naukowo-techniczne powinny włączyć się aktywnie w realizację programu Horyzont Europa, by z jednej strony w ramach partnerstwa europejskiego zapewnić rozwój niskoemisyjnej gospodarki kraju, a z drugiej - uzyskać na ten rozwój środki finansowe.

Szczególną rolę w tej transformacji szeregu sektorów, w tym przede wszystkim energetyki, ma do odegrania przemysł naftowy i gazowniczy, który mając doświadczenie związane z węglowodorami i odpowiednie zaplecze infrastrukturalne, już dzisiaj oferuje ciekawe rozwiązania technologiczne z obszaru biopaliw czy wykorzystania wodorowego nośnika energii.

Należy też podkreślić kluczową rolę gazownictwa w całym procesie przejścia z paliw kopalnych na czystą energię.

Polska w latach 2007-2020, realizując projekty w Programie Operacyjnym Infrastruktura i Środowisko w aspekcie zwiększenia bezpieczeństwa energetycznego kraju, finansowane z funduszy europejskich, już prowadziła prace przygotowawcze do obecnych wyzwań. Projekty te uwzględniały m.in. podwyższenie funkcjonalności budowanego systemu gazowego, by umożliwić przesył innych paliw gazowych, czy różnorodne wykorzystanie sieci gazowych.

Pierwszoplanowym zagadnieniem podejmowanym obecnie przez sektor gazowniczy jest określenie wymagań dotyczących stanu technicznego gazociągów zdolnych do przesyłania gazu ziemnego z domieszką wodoru, jak i samego wodoru, uwzględniających równocześnie wpływ ww. mediów na całokształt sieci, w tym na urządzenia końcowe.

\section{Literatura}

Balcewicz J., 2020. Kształtowanie przyszłości cyfrowej Europy nowa cyfrowa strategia UE. $<$ https://cyberpolicy.nask.pl/ksztaltowanie-przyszlosci-cyfrowej-europy-nowa-cyfrowa-strategiaue/> (dostęp: 06.08.2020).

DigitalEurope, 2019. Silniejsza cyfrowa Europa. <https://www. digitaleurope.org/wp/wp-content/uploads/2019/03/Manifesto_ Polish_WEB.pdf $>$ (dostęp: 06.08.2020).

Dorociak M., Tomecki M., 2019. Wodorowa alternatywa. Raport 2019. 300Gospodarka, Warszawa. <https://static.300gospodarka.pl/media/2019/04/alternatywa_wodorowa_raport.pdf $>$ (dostęp: 10.04.2020).

Jaworski J., Kukulska-Zając E., Kułaga P., 2019. Wybrane zagadnienia dotyczące wpływu dodatku wodoru do gazu ziemnego na 
elementy systemu gazowniczego. Nafta-Gaz, 10: 625-632. DOI: 10.18668/NG.2019.10.04.

Komisja Europejska, 2019a. Horyzont Europa: inwestycje, które kształtują naszą przyszłość. <https://ec.europa.eu/info/sites/ info/files/horizon_europe_pl_-_inwestycje_ktore_ksztaltuja_nasza_przyszlosc.pdf $>$ (dostęp: 25.07 .2020$)$.

Komisja Europejska, 2019b. Komunikat Komisji do Parlamentu Europejskiego, Rady Europejskiej, Europejskiego Komitetu Ekonomiczno-Społecznego i Komitetów Regionów. Europejski Zielony Ład. COM(2019) 640 final. Bruksela, 11.12.2019. $<$ https://ec.europa.eu/transparency/regdoc/rep/1/2019/PL/COM2019-640-F1-PL-MAIN-PART-1.PDF> (dostęp: 25.07.2020).

Komisja Europejska, 2020. Doskonała baza naukowa - Działania „Maria Skłodowska-Curie”. <https://cordis.europa.eu/programme/id/H2020-EU.1.3./pl> (dostęp: 17.08.2020).

Łoskot-Strachota A., 2020. Unijna strategia wodorowa. <https:// www.osw.waw.pl/pl/publikacje/analizy/2020-07-10/unijna-strategia-wodorowa> (dostęp: 06.08.2020).
Międzynarodowa Agencja Energii, 2019. Przyszłość wodoru. Raport technologiczny. <https://www.iea.org/reports/the-future-ofhydrogen> (dostęp: 20.07.2020).

Regionalne Centrum Innowacji i Transferu Technologii, 2020. Horizon Europe - nowy Program Ramowy UE na lata 2021-2027. <https:// innowacje.zut.edu.pl/aktualnosci/horizon-europe-nowy-programramowy-ue-na-lata-2021-2027> (dostęp: 20.07.2020).

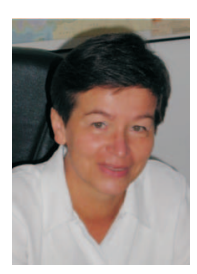

Dr hab. inż. Maria CIECHANOWSKA, prof. INiG - PIB

Dyrektor Instytutu Nafty i Gazu -

Państwowego Instytutu Badawczego

ul. Lubicz 25 A

31-503 Kraków

E-mail: maria.ciechanowska@inig.pl

\section{OFERTA BADAWCZA ZAKŁADU} TECHNIKI STRZELNICZEJ

- konstrukcja urządzeń strzelniczych, przeznaczonych do udostępniania poziomów ropo- i gazonośnych;

- opracowywanie technologii i metod prowadzenia prac udostępniających, przy wykorzystaniu wtasnych rozwiązań konstrukcyjnych sprzętu strzelniczego;

- konstrukcja urządzeń strzelniczych, przeznaczonych do prac specjalnych i ratunkowych w otworach wiertniczych (korki detonacyjne, tadunki o dziataniu pionowym, obcinacze rur oktadzinowych i ptuczkowych);

- $\quad$ przywracanie cyrkulacji w odwiercie - uwalnianie przewodu wiertniczego;

- intensyfikacja oraz stymulacja przyptywów medium do odwiertu (szczelinowanie strefy przyotworowej ztoża prochowymi generatorami ciśnienia);

- badania atestacyjno-wytrzymałościowe sprzętu strzałowego;

- matoseryjna produkcja urządzeń strzelniczych (perforatory, korki detonacyjne, obcinacze do rur).

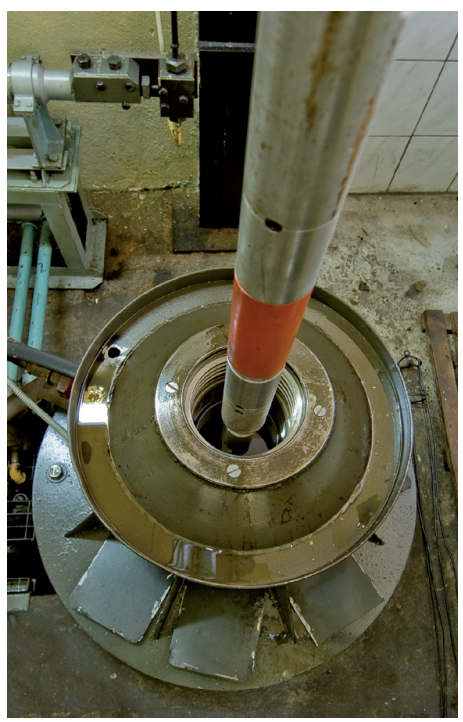

INSTYTUT NAFTY I GAZU - Państwowy Instytut Badawczy 